\title{
ZMYM3 wt Allele
}

National Cancer Institute

\section{Source}

National Cancer Institute. ZMYM3 wt Allele. NCI Thesaurus. Code C101618.

Human ZMYM3 wild-type allele is located in the vicinity of Xq13.1 and is approximately 16 $\mathrm{kb}$ in length. This allele, which encodes zinc finger MYM-type protein 3, plays a role in the regulation of chromatin remodeling, cell morphology and cytoskeletal organization. A chromosomal translocation $(X ; 13)$ involving this gene is associated with $X$-linked mental retardation. 